\title{
Effects of Selected Inherited Factors on Susceptibility to SARS-CoV-2 Infection and COVID-19 Progression
}

\author{
Jaroslav A. HUBACEK ${ }^{1,2}$ \\ ${ }^{1}$ Experimental Medicine Centre, Institute for Clinical and Experimental Medicine, Prague, Czech \\ Republic, ${ }^{2}$ Third Department of Internal Medicine, First Faculty of Medicine, Charles University, \\ Prague, Czech Republic
}

Received May 17, 2021

Accepted July 27, 2021

\begin{abstract}
Summary
Genetic predispositions may influence geographical and interethnic differences in COVID-19 prevalence and mortality in affected populations. Of the many genes implicated in COVID-19 progression, a substantial number have no direct functional link on virus transfer/viability or on the host immune system. To address this knowledge deficit, a large number of in silico studies have recently been published. However, the results of these studies often contradict the findings of studies involving real patients. For example, the ACE2 has been shown to play an important role in regulating coronavirus entry into cells, but none of its variations have been directly associated with COVID19 susceptibility or severity. Consistently was reported that increased risk of COVID-19 is associated with blood group A and with the APOE4 allele. Among other genes with potential impacts are the genes for CCR5, IL-10, CD14, TMPRSS2 and angiotensinconverting enzyme. Variants within the protein-coding genes OAS1 and LZTFL1 (transferred to the human genome from Neanderthals) are understood to be among the strongest predictors of disease severity. The intensive research efforts have helped to identify the genes and polymorphisms that contribute to SARS-CoV-2 infection and COVID-19 severity.
\end{abstract}

\section{Key words}

Genetics - Population - Polymorphism - Susceptibility - SARSCoV-2 • COVID-19

\section{Corresponding author}

J. A. Hubacek, Experimental Medicine Centre, Institute for Clinical and Experimental Medicine, Videnska 1958/9, Prague 4, 14021, Czech Republic. E-mail: jahb@ikem.cz

\section{Introduction}

Severe acute respiratory syndrome RNA coronavirus 2 (SARS-CoV-2) infection causes the pneumonia-associated disease known as COVID-19 (COrona VIrus Disease - 2019) (Coronaviridae Study Group 2020). First reported in Wuhan, China in December 2019, the disease has since spread rapidly to become a global pandemic (Liu et al. 2020). In comparison with previous coronavirus diseases such as MERS (Middle East Respiratory Syndrome) and SARS (Severe Acute Respiratory Syndrome), COVID-19 is characterised by relatively low mortality but being far more contagious (Petrosillo et al. 2020, Berekaa 2021).

Based on worldwide outcomes, it was quickly established that males, the elderly, obese and diabetics are typically at increased risk of COVID-19 morbidity and mortality (Hippisley-Cox et al. 2020).

Importantly, significant interethnic variability in COVID-19 prevalence, severity and associated mortality has been reported (Hastie et al. 2020, Lassale et al. 2020, Raisi-Estabragh et al. 2020). Accordingly, much attention has focused on the influence of genes with interethnic allelic differences on COVID-19 susceptibility and/or severity, irrespective of their involvement in the host immune system.

In fact however, hundreds of SNPs exhibit significant differences in allelic and genotype frequencies between ethnicities (Huang et al. 2015). It is estimated that about $15 \%$ of all existing genetic variants within the human genome are population- or ethnicity-specific, and 
even variants common within one ethnicity may be completely missing in others (Barbujani et al. 1997). Notable examples include variants within the genes for apolipoprotein L1, alcohol dehydrogenase, human homeostatic iron regulator protein (HFE) or genes predisposing to diabetes (Beckman et al. 1997, Borinskaya et al. 2009, Nadkarni et al. 2018, Hubáček et al. 2020).

Recently, there has been a rapid and significant increase in the publication of in silico studies. These studies used freely available ecological data on disease prevalence and severity as well as genotype distributions (coming often from small independent studies) within populations, but lack direct access to patient and control data. They typically compared the reported numbers of fatalities per million inhabitants, the total number of reported cases, or the number of total cases per million inhabitants. However, these data, collected from dozens of European and Asian countries during the first COVID-19 wave, often contradict the findings of casecontrol studies (see analysis of $A C E$ and $A C E 2$ genes below), which evaluate samples collected directly from SARS-CoV-2-positive subjects in order to assess COVID-19 susceptibility and severity.

Simply, the fact that there are differences in disease prevalence at the population level are attributable not only to prevalence of risk factors or genetic predispositions (Vašků 2020, Ovsyannikova et al. 2020) but also to the imposition of government restrictions. For example, countries almost unaffected during the first wave in the spring of 2020, such as Czech Republic, Croatia and Poland, later experienced very high rates. And while countries like Belgium and France had two mortality peaks during the spring and winter of 2020 , other countries such as Norway or Iceland reported relatively low COVID-19-associated mortality throughout the pandemic (online at //covid19-countryoverviews.ecdc.europa.eu). In this context, therefore, estimating the risk status of variants is dependent to a large degree on the exact dates of data collection.

Ethnic admixture plays another important role. As evidenced during the first wave, the highest mortality rates were in countries such as the UK, France, Italy and Spain where the proportion of non-European immigrants is very high. A number of studies have confirmed that ethnicity is one of the most important factors in disease susceptibility and severity (Hastie et al. 2020, RaisiEstabragh et al. 2020, Lassale et al. 2020): Africans are considered at highest risk followed by Asians and then
Caucasians, the ethnic group at lowest risk.

This review present the selected examples of associations between various genetic variants and COVID-19 susceptibility or severity.

\section{AB0 blood groups}

Rather surprisingly, the $\mathrm{AB} 0$ blood group system was the main subject of interest for studies investigating the association between inherited factors and COVID-19.

To date, there have been more than 40 reports and they were excellently summarized by Pendu et al. (2021) and within some meta analyses (Pourali et al. 2020, Wu et al. 2020 and Liu et al. 2020). Although largely heterogeneous and characterized by a number of discrepancies, almost all of these studies report lower risk of severe COVID-19 in subjects with blood group 0 . Conversely, individuals with blood group A seem to be at highest risk according to these reports. Blood groups $B$ and $\mathrm{AB}$ are generally evaluated as neutral, but with a slight increased risk of severe COVID-19 in populations around the Persian Gulf. However, given AB is by far the least common blood group ( $\sim 5 \%)$ regardless of ethnicity, no definitive conclusion on the association with $\mathrm{AB}$ blood group can be drawn.

Based on the evidence, the $\mathrm{AB} 0$ blood group system plays an important role in determining COVID-19 outcomes. It is in contrast with the fact that the highest frequency of blood group 0 usually occurs in Africans $(\sim 50 \%)$ and Hispanics $(\sim 60 \%)$. These ethnicities are at higher risk of COVID-19 risk compared to Caucasians, who have the lowest prevalence $(\sim 40 \%)$ of blood group 0. In some European regions, however, blood group A is most common (Dean 2012).

In particular, according to one genome-wide association study (Severe Covid-19 GWAS Group 2020), significant signals within loci of the AB0 blood group system confirmed benefit in blood group 0 and increased risk in blood group A. Another study demonstrated that genetically determined plasma levels of $\mathrm{AB} 0$ proteins are causally associated with COVID-19 risk and severity (Hernández Cordero et al. 2021).

\section{Apolipoprotein E}

APOE (apolipoprotein E) is a protein-coding gene expressed in almost all human tissues. Exhibiting extreme pleiotropic complexity, APOE plays critical roles in lipid metabolism, cardiovascular disease and 
Alzheimer's disease (Mahley 2016) as well as immune responses (Gale et al. 2014); or hypertension (Shi et al. 2018) which is understood to increase COVID-19 severity.

There are three major $A P O E$ alleles: $A P O E 2$ (rs7412; Arg158>Cys), APOE3 (the most common worldwide) and APOE4 (an ancestral allele with deleterious effects on many diseases; rs429358; Cys112>Arg).

Associations with COVID-19 were first observed in subjects from the UK Biobank community cohort. This study found that APOE4E4 homozygotes had an almost 2.5-fold increased risk of severe COVID19, and association was valid even after excluding individuals with diabetes, hypertension and cardiovascular disease (Kuo et al. 2020). Similarly, Del Ser et al. (2021) found that elderly carriers (aged over 75 years) of APOE4 alleles were at increased risk of developing mild or moderate COVID-19 symptoms. In a Czech study involving asymptomatic and symptomatic non-hospitalised subjects, carriers of at least one APOE4 allele were significantly more common in symptomatic COVID-19 subjects than in general population controls. However, no differences between asymptomatic SARSCoV-2-positive subjects and general controls were observed (Hubacek et al. 2021a).

Interestingly, all of the above studies are in agreement with an in silico study by Goldstein et al. (2020). They concluded that prevalence of the APOE4 allele in black Africans (population frequency: $30-40 \%$ ) compared to Caucasians (population frequency $\sim 7-20 \%$ ) and Asians (population frequency: $\sim 5-15 \%$ ) (Abondio et al. 2019) explains the high COVID-19 severity and mortality within this ethnic group.

\section{ACE2 and TMPRSS2}

The ACE2 and TMPRSS2 genes coding two proteins, serving as a SARS-Cov-2 entry gateway into the cell - ACE2 and TMPRSS2 - were the first had attracted great interest (Hoffmann et al. 2020).

Studies show that the TMPRSS2 (transmembrane protease, serine 2) enzyme activates the spread and pathogenesis of human coronaviruses in the infected host (Shirato et al. 2018) and ACE2 (angiotensin-converting enzyme 2) acts as a receptor, facilitating the entry of the COVID-19 virus into cells (Bourgonje et al. 2020).

Most studies conclude that the genetic variability of $A C E 2$ in humans is lower than that of other genes, with no significant effects on COVID-19 progression. Even whole-exome sequencing analyses (Gómez et al. 2020, Torre-Fuentes et al. 2021) of ACE2 coding regions have failed to identify a polymorphism that might influence disease risk or outcomes. Thus, albeit there is wide list of theoretical results from in silico studies that used molecular simulations, computational analyses, and different web-based tools to suggest interactions between different $A C E 2$ variants and protein functions, these were so far not confirmed in vivo.

TMPRSS2 has also attracted scientists to perform a list of in silico analysis (Srivastava et al. 2020) a number of promising in vivo studies have also been published. For example, a large Italian study detected an association between a cluster of five variants within the TMPRSS2/MX1 gene loci and COVID-19 severity (Andolfo et al. 2021). In Spanish subjects, variability within TMPRSS2 was also associated with COVID-19 severity (Torre-Fuentes et al. 2021). Altogether, TMPRSS2 variability seems to exert more of an influence on COVID-19 progression than $A C E 2$.

\section{Angiotensin-converting enzyme}

ACE (ACE1, angiotensin I-converting enzyme, alias kininase II) is a key member of the reninangiotensin-aldosterone system (RAAS). Like ACE2, another RAAS family member, ACE acts as a receptor for SARS-CoV-2 (Hoffmann et al. 2020). Intron 16 of the ACE gene contains a functional insertion/deletion (I/D) polymorphism, $287 \mathrm{bp}$ (rs4646994), the deletion of which is associated with increased enzyme activity and concentration (Cambien et al. 1988).

Polymorphisms within the ACE gene are among the heavily discussed variants with the potential to influence COVID-19 outcomes. However, most of the studies on this topic have been performed under in silico protocols. Unfortunately, also data on frequencies of $A C E$ genotypes are often limited to small or non-representative samples, producing conflicting results.

The first large studies performed by Delanghe et al. (2020a and 2020b) identified the I/I genotype as deleterious. In contrast, studies by Bellone and Calvisi (2020) and Yamamoto et al. (2020) identified the D allele as a predictive marker of increased COVID-19 severity. Another study found no association between the ACE I/D polymorphism and SARS-2 infection or COVID-19 severity (Saadat 2020). 
Unfortunately, even in vivo studies have failed to clarify these discrepancies. Verma et al. (2021) found an association between the D/D genotype and COVID-19 in an Asian population. Severe COVID-19 is also associated with the ACE D/D genotype in Spanish patients (Gómez et al. 2020). In contrast, our Central European study found an association between the I/I genotype and symptomatic progress of COVID-19 in non-hospitalised patients (Hubacek et al. 2021b).

The entire situation is here further complicated by the fact, that ACE inhibitors are some of the most prescribed blood pressure-lowering drugs. And while they have been shown to offer protection against both COVID-19 susceptibility and severity in Europeans, they pose significantly higher risk for Black Africans (Hippisley-Cox et al. 2020). To date, no study has examined the potential interaction between ACE inhibitors and $A C E$ polymorphism in COVID-19 patients.

\section{"Neanderthal" polymorphisms}

Two variants with considerable effects on COVID-19 susceptibility and severity entered the human genome by gene flow from Neanderthals.

The rs35044562 (Zeberg and Pääbo 2020) polymorphism is located within the LZTFL1 (leucine zipper transcription factor-like 1) loci and is associated with an approximate $70 \%$ increased risk of hospitalisation due to COVID-19. Further genes located in identical loci (3p21.31) are associated with enhanced complement activation (Valenti et al. 2020). The chemokine receptors CCR9, CCR1 and CXCR6 are reported to have a potentially causal association with COVID-19. Additionally, the gene for FYCO1 (FYVE and coiled-coil domain-containing 1) and the gene for SLC6A20 (solute carrier family 6, proline IMINO transporter, member 20), which interacts with ACE2, are located in the same region (Severe Covid-19 GWAS Group 2020).

According to genome-wide association (GWA) studies, OAS-1 (oligoadenylate synthetase 1) is another protein of Neanderthal origin playing a role in immune responses against RNA viruses, with functional consequences for infection (Zhou et al. 2020, PairoCastineira et al. 2021). The OAS proteins OAS1, OAS2 and OAS3 activate RNAases, which in turn break down and eliminate endogenous as well as viral RNA (Kristiansen et al. 2010). Interestingly, variant within OAS1 has been previously associated with the susceptibility to the SARS infection (He et al. 2006).

Although the above studies boast relatively high numbers of examined subjects and odds ratios, further independent studies are warranted.

\section{Other mentioned genetic polymorphisms}

Several other genes have been investigated using similar approaches as mentioned in details above. An in silico study found that human homeostatic iron regulator protein (HFE, Cys282Tyr polymorphism, rs1800562), which leads to iron overload and haemochromatosis, has no significant correlation with COVID-19 prevalence (Delange et al. 2020a). The other haemochromatosis-associated polymorphism Asp63His has yet to be examined.

Another extensive in silico analyses (Kim and Jeong 2020, Pati et al. 2021a) of publicly available data (mostly WHO and 1000 genome project), as well as in vivo study (Zhang et al. 2020) pointed on potential importance of the IFITM (interferon-induced transmembrane proteins, involved in restriction of both viruses entry as well as viruses replications, especially IFITM3 seems to be of importance) gene family in determination of COVID-19 severity and fatality rate.

HLA (Human Leucocyte Antigen) complex is involved also in effective defense mechanism against viruses. Unfortunately, the genes coding the HLA proteins are among the most polymorphic in humans. So far performed studies were recently summarized (FrickeGalindo and Falfán-Valencia 2021) and alleles associated with low risk (for example $-A^{*} 02: 02$ or $-C^{*} 12: 03$ ) as well as with mortality $\left(C^{*} 05,-B^{*} 51: 01\right.$ or $\left.-D Q B 1^{*} 04\right)$ were detected.

The functional rs2569190 polymorphism within the $\mathrm{CD} 14$ receptor gene has been intensively discussed in association with different infections (Guo et al. 2020, Zhao et al. 2013). One in silico study found an association between the $\mathrm{T}$ allele and SARS-CoV-2 infection and mortality in European populations (Pati et al. 2021b).

In UK Biobank subjects, the minor TT genotype of rs17775810 sigma-1 receptor (SIR, regulates inflammation due to cytokine production inhibition) was associated with lower death rates in comparison to carriers of at least one $C$ allele (Lehrer and Rheinstein 2021).

In Czech subjects, the $32 \mathrm{bp}$ deletion (rs333) allele within the CCR5 (CC chemokine receptor 5) gene, which protects homozygote carriers against HIV infection 
(Samson et al. 1996), was shown to protect against symptomatic COVID-19 progression (Hubacek et al. 2021c). Deletion allele was also less frequent in Spanish patients, hospitalized with COVID-19 (Cuesta-Llavona et al. 2021). In contrast, a large study of German stemcell donors (Bernas et al. 2021) detected no association between this deletion and COVID-19 severity. Interestingly, CCR5 is located within close proximity of the LZTFL1 gene (see above).

Further COVID-19-associated signals within regions encoding genes for tyrosine kinase 2 (TYK2), dipeptidyl peptidase 9 (DPP9) and the interferon receptor gene (IFNAR2) have also been detected using the GWA model (Pairo-Castineira et al. 2021).

As vitamin D deficiency is much more common within the groups who are at highest risk of severe COVID-19 (Benskin 2020), vitamin D receptor (VDR) is another plausible candidate to study. Indeed, in silico study (Karcioglu Batur and Hekim 2021) suggest positive correlations between the prevalence and mortality rates and rs7041 variant within the VDR loci. Unfortunately, representative in vivo studies are missing so far.

The identical is valid for cytokines. Albeit cytokine variability $(I L-6, I L-10, I L 1-R N, T N F-\alpha, \ldots)$ has definitely high potential to influence COVID-19 induced cytokine storm (Paim et al. 2021) relevant studies are generally missing.

\section{Conclusions}

It is clear that the causes of COVID-19 are multifactorial. Disease susceptibility, resistance and outcomes are characterized by high interindividual heterogeneity. The disease is not only influenced by accompanying factors such as obesity, hypertension and diabetes, but also by important predictors such as ethnicity (Hippisley-Cox et al. 2020) and genetic predisposition (Vasku 2020, Ovsyannikova et al. 2020).

Thanks to the intensive efforts of many researchers worldwide, the genes and polymorphisms that contribute to SARS-CoV-2 infection and COVID-19 severity are now better understood. There is a long list of genes and variants with the potential to affect SARSCoV-2 susceptibility. However, only a few genetic determinants of SARS-CoV-2 infection and COVID-19 severity seems to have consistent effects (Table 1), and many of in silico suggested associations were not conclusively examined and confirmed in vivo. This is definitely caused also by the fact, that number of examined subjects is often relatively low (not exceptions are studies with less than 30 subjects). COVID-19 association studies had collected and screened of magnitude less subjects than studies focused on other communicable or non-communicable diseases. Interestingly however, some of them overlap the candidates (for example OAS-1 or CD14) associated with the previous SARS infection (Dos Santos et al. 2021).

It should also be noted that the inclusion criteria applied are highly variable, with SARS-CoV-2-positive cases ranging from asymptomatic through mild-to-severe to fatalities. Finally, ethnic differences in disease susceptibility and severity highlight the heterogeneity of the genes and variants involved.

Over-activation of the immune system is an acknowledged hallmark of severe COVID-19 cases (Mehta et al. 2020, Paces et al. 2020). However, not all of the genes of interest thus far described are known to have important or at least some roles in the immune system.

Table 1. Brief summary of selected examples of COVID-19 associated genes.

$\begin{array}{lll}\text { Gene } & \text { Effect }\end{array}$

$\begin{aligned} & \text { ABO blood groups } \\ & \text { APOE }\end{aligned}$
APOE4 (rs429358) allele is associated with increased risk
Controversial roles - insertion (rs4646994) allele seems to be risky in Caucasians, deletion
allele in Asians
Cluster of polymorphisms associated with increased risk - effect due to the activation of
RNAses
rsTFL1


Therefore, it cannot be discounted that they serve as markers in high linkage disequilibrium for some adjacent clustering genes with causal variants.

A simple, quick and inexpensive test aimed at predicting symptomatic COVID-19 based on individual DNA polymorphisms would be helpful both in distinguishing between subjects at high and low risk and importantly, also in estimating disease severity. Such a test would require a wide list of polymorphisms to be examined simultaneously. Similarly to other diseases (Talmud et al. 2015, Mistry et al. 2018) creation of the (poly)genetic risk score (Choi et al. 2020) reflecting the host ability to affect the individual's sensitivity to COVID-19 could be important.
Further studies aimed at elucidating the complex role played by genetic predispositions are needed in order to improve timely detection in at-risk subjects and management of the ongoing COVID-19 pandemic.

\section{Conflict of Interest}

There is no conflict of interest.

\section{Acknowledgements}

The study was supported by the Ministry of Health of the Czech Republic - under the Conceptual Development of Research Organizations programme (,Institute for Clinical and Experimental Medicine - IKEM, IN 00023001“).

\section{References}

ABONDIO P, SAZZINI M, GARAGNANI P, BOATTINI A, MONTI D, FRANCESCHI C, LUISELLI D, GIULIANI $\mathrm{C}$ : The genetic variability of APOE in different human populations and its implications for longevity. Genes (Basel) 10: 222, 2019. https://doi.org/10.3390/genes10030222

ANDOLFO I, RUSSO R, LASORSA VA, CANTALUPO S, ROSATO BE, BONFIGLIO F, FRISSO G, ABETE P, CASSESE GM, SERVILLO G, ESPOSITO G, GENTILE I, PISCOPO C, VILLANI R, FIORENTINO G, CERINO P, BUONERBA C, PIERRI B, ZOLLO M, IOLASCON A, CAPASSO M: Common variants at 21q22.3 locus influence MX1 and TMPRSS2 gene expression and susceptibility to severe COVID-19. iScience 24: 102322, 2021. https://doi.org/10.1016/j.isci.2021.102322

BARBUJANI G, MAGAGNI A, MINCH E, CAVALLI-SFORZA LL: An apportionment of human DNA diversity. Proc Natl Acad Sci U S A 94: 4516-4519, 1997. https://doi.org/10.1073/pnas.94.9.4516

BECKMAN LE, SAHA N, SPITSYN V, VAN LANDEGHEM G, BECKMAN L: Ethnic differences in the HFE codon 282 (Cys/Tyr) polymorphism. Hum Hered 47: 263-267, 1997. https://doi.org/10.1159/000154422

BELLONE M, CALVISI SL: ACE polymorphism and COVID-19-related mortality in Europe. Mol Med (Berl) 98: 1505-1509, 2020. https://doi.org/10.1007/s00109-020-01981-0

BENSKIN LL: A basic review of the preliminary evidence that COVID-19 risk and severity is increased in vitamin D deficiency. Front Public Health 8: 513, 2020. https://doi.org/10.3389/fpubh.2020.00513

BEREKAA MM: Insights into the COVID-19 pandemic: Origin, pathogenesis, diagnosis, and therapeutic interventions. Front Biosci (Elite Ed) 13: 117-139, 2020. https://doi.org/10.2741/874

BERNAS SN, BALDAUF H, WENDLER S, HEIDENREICH F, LANGE V, HOFMANN JA, SAUTER J, SCHMIDT AH, SCHETELIG J: CCR5 32 mutations do not determine COVID-19 disease course. Int J Infect Dis 105 : 653-655, 2021. https://doi.org/10.1016/j.ijid.2021.02.108

BORINSKAYA S, KAL'INA N, MARUSIN A, FASKHUTDINOVA G, MOROZOVA I, KUTUEV I, KOSHECHKIN V, KHUSNUTDINOVA E, STEPANOV V, PUZYREV V, YANKOVSKY N, ROGAEV E: Distribution of the alcohol dehydrogenase ADH1B*47His allele in Eurasia. Am J Hum Genet 84: 89-92, 2009. https://doi.org/10.1016/j.ajhg.2008.12.007

BOURGONJE AR, ABDULLE AE, TIMENS W, HILLEBRANDS JL, NAVIS GJ, GORDIJN SJ, BOLLING MC, DIJKSTRA G, VOORS AA, OSTERHAUS AD, VAN DER VOORT PH, MULDER DJ, VAN GOOR H: Angiotensin-converting enzyme 2 (ACE2), SARS-CoV-2 and the pathophysiology of coronavirus disease 2019 (COVID-19). J Pathol 251: 228-248, 2020. https://doi.org/10.1002/path.5471

CAMBIEN F, ALHENC-GELAS F, HERBETH B, ANDRE JL, RAKOTOVAO R, GONZALES MF, ALLEGRINI J, BLOCH C: Familial resemblance of plasma angiotensin-converting enzyme level: the Nancy Study. Am J Hum Genet 43: 774-780, 1988. 
CHOI SW, MAK TS, O'REILLY PF: Tutorial: a guide to performing polygenic risk score analyses. Nat Protoc 15: 2759-2772, 2020. https://doi.org/10.1038/s41596-020-0353-1

CORONAVIRIDAE STUDY GROUP OF THE INTERNATIONAL COMMITTEE ON TAXONOMY OF VIRUSES: The species Severe acute respiratory syndrome-related coronavirus: classifying $2019-\mathrm{nCoV}$ and naming it SARS-CoV-2. Nat Microbiol 5: 536-544, 2020. https://doi.org/10.1038/s41564-020-0695-Z

CUESTA-LLAVONA E, GÓMEZ J, ALBAICETA GM, AMADO-RODRÍGUEZ L, GARCÍA-CLEMENTE M, GUTIÉRREZ-RODRÍGUEZ J, LÓPEZ-ALONSO I, HERMIDA T, ENRÍQUEZ AI, HERNÁNDEZGONZÁLEZ C, GIL-PEÑA H, DOMÍNGUEZ-GARRIDO E, PÉREZ-OLIVEIRA S, ALVAREZ V, LÓPEZLARREA C, SUAREZ-ALVAREZ B, TRANCHE S, JIMENO-DEMUTH FJ, COTO E: Variant-genetic and transcript-expression analysis showed a role for the chemokine-receptor CCR5 in COVID-19 severity. Int Immunopharmacol 98: 107825, 2021. https://doi.org/10.1016/j.intimp.2021.107825

DEAN L: ABO blood group. In: Medical Genetics Summaries [Internet]. PRATT VM, SCOTT SA, PIRMOHAMED M, ESQUIVEL B, KANE MS, KATTMAN BL, MALHEIRO AJ (eds), Bethesda (MD): National Center for Biotechnology Information (US), 2012 (updated 2015 Jul 27).

DELANGHE JR, SPEECKAERT MM, DE BUYZERE ML: COVID-19 infections are also affected by human ACE1 D/I polymorphism. Clin Chem Lab Med 58: 1125-1126, 2020a. https://doi.org/10.1515/cclm-2020-0425

DELANGHE JR, SPEECKAERT MM, DE BUYZERE ML: The host's angiotensin-converting enzyme polymorphism may explain epidemiological findings in COVID-19 infections. Clin Chim Acta 505: 192-193, 2020b. https://doi.org/10.1016/j.cca.2020.03.031

DEL SER T, FERNÁNDEZ-BLÁZQUEZ MA, VALENTÍ M, ZEA-SEVILLA MA, FRADES B, ALFAYATE E, SAIZ L, CALERO O, GARCÍA-LÓPEZ FJ, RÁBANO A, MEDINA M, CALERO M: Residence, clinical features, and genetic risk factors associated with symptoms of COVID-19 in a cohort of older people in Madrid. Gerontology 67: 281-289, 2021. https://doi.org/10.1159/000513182

Dos SANTOS ACM, Dos SANTOS BRC, Dos SANTOS BB, DE MOURA EL, FERREIRA JM, Dos SANTOS LKC, OLIVEIRA SP, DIAS RBF, PEREIRA E SILVA AC, DE FARIAS KF, DE SOUZA FIGUEIREDO EVM: Genetic polymorphisms as multi-biomarkers in severe acute respiratory syndrome (SARS) by coronavirus infection: A systematic review of candidate gene association studies. Infect Genet Evol 93: 104846, 2021. https://doi.org/10.1016/j.meegid.2021.104846

FRICKE-GALINDO I, FALFÁN-VALENCIA R: Genetics insight for COVID-19 susceptibility and severity: A review. Front Immunol 12: 622176, 2021. https://doi.org/10.3389/fimmu.2021.622176

GALE SC, GAO L, MIKACENIC C, COYLE SM, RAFAELS N, MURRAY DUDENKOV T, MADENSPACHER JH, DRAPER DW, GE W, ALOOR JJ, AZZAM KM, LAI L, BLACKSHEAR PJ, CALVANO SE, BARNES KC, LOWRY SF, CORBETT S, WURFEL MM, FESSLER MB: APO 4 is associated with enhanced in vivo innate immune responses in human subjects. J Allergy Clin Immunol 134: 127-134, 2014. https://doi.org/10.1016/j.jaci.2014.01.032

GOLDSTEIN MR, POLAND GA, GRAEBER ACW: Does apolipoprotein E genotype predict COVID-19 severity? QJM 113: 529-530, 2020. https://doi.org/10.1093/qjmed/hcaa142

GÓMEZ J, ALBAICETA GM, GARCÍA-CLEMENTE M, LÓPEZ-LARREA C, AMADO-RODRÍGUEZ L, LOPEZALONSO I, HERMIDA T, ENRIQUEZ AI, HERRERO P, MELÓN S, ALVAREZ-ARGÜELLES ME, BOGA JA, ROJO-ALBA S, CUESTA-LlAVONA E, ALVAREZ V, LORCA R, COTO E: Angiotensinconverting enzymes (ACE, ACE2) gene variants and COVID-19 outcome. Gene 762: 145102, 2020. https://doi.org/10.1016/j.gene.2020.145102

GUO Y, LIU Y, SONG J, LIU P, WU S, TAN Y, FAN F, CHEN Z: Association of CD14 rs2569190 G/A genetic polymorphism with the severity of enterovirus 71 infection in Chinese children. Virology 548: 25-30, 2020. https://doi.org/10.1016/j.virol.2020.06.001

HASTIE CE, MACKAY DF, HO F, CELIS-MORALES CA, KATIKIREDDI SV, NIEDZWIEDZ CL, JANI BD, WELSH P, MAIR FS, GRAY SR, O'DONNELL CA, GILL JM, SATTAR N, PELL JP: Vitamin D concentrations and COVID-19 infection in UK Biobank. Diabetes Metab Syndr 14: 561-565, 2020. Erratum in: Diabetes Metab Syndr 14: 1315-1131, 2020. https://doi.org/10.1016/j.dsx.2020.07.021 
HE J, FENG D, De VLAS SJ, WANG H, FONTANET A, ZHANG P, PLANCOUlAine S, TANG F, ZHAN L, YANG H, WANG T, RICHARDUS JH, HABBEMA JD, CAO W: Association of SARS susceptibility with single nucleic acid polymorphisms of OAS1 and MxA genes: a case-control study. BMC Infect Dis 6: 106, 2006. https://doi.org/10.1186/1471-2334-6-106

HERNÁNDEZ CORDERO AI, LI X, MILNE S, YANG CX, BOSSÉ Y, JOUBERT P, TIMENS W, VAN DEN BERGE M, NICKLE D, HAO K, SIN DD: Multi-omics highlights ABO plasma protein as a causal risk factor for COVID-19. Hum Genet 140: 969-979, 2021. https://doi.org/10.1007/s00439-021-02264-5

HIPPISLEY-COX J, YOUNG D, COUPLAND C, CHANNON KM, TAN PS, HARRISON DA, ROWAN K, AVEYARD P, PAVORD ID, WATKINSON PJ: Risk of severe COVID-19 disease with ACE inhibitors and angiotensin receptor blockers: cohort study including 8.3 million people. Heart 106: 1503-1511, 2020. https://doi.org/10.1136/heartjnl-2020-317393

HOFFMANN M, KLEINE-WEBER H, SCHROEDER S, KRÜGER N, HERRLER T, ERICHSEN S, SCHIERGENS TS, HERRLER G, WU NH, NITSCHE A, MÜLLER MA, DROSTEN C, PÖHLMANN S: SARS-CoV-2 cell entry depends on ACE2 and TMPRSS2 and is blocked by a clinically proven protease inhibitor. Cell 181: 271-280.e8, 2020. https://doi.org/10.1016/j.cell.2020.02.052

HUANG T, SHU Y, CAI YD: Genetic differences among ethnic groups. BMC Genomics 16: 1093, 2015. https://doi.org/10.1186/s12864-015-2328-0

HUBÁČEK JA, ŠEDOVÁ L, OLIŠAROVÁ V, ADÁMKOVÁ V, TÓTHOVÁ V: Different prevalence of T2DM risk alleles in Roma population in comparison with the majority Czech population. Mol Genet Genomic Med 8: e1361, 2020. https://doi.org/10.1002/mgg3.1361

HUBACEK JA, DLOUHA L, DUSEK L, MAJEK O, ADAMKOVA V: Apolipoprotein E4 allele in subjects with COVID-19. Gerontology 67: 320-322, 2021a. https://doi.org/10.1159/000516200

HUBACEK JA, DUSEK L, MAJEK O, ADAMEK V, CERVINKOVA T, DLOUHA D, ADAMKOVA V: ACE I/D polymorphism in Czech first-wave SARS-CoV-2-positive survivors. Clin Chim Acta 519: 206-209, 2021b. https://doi.org/10.1016/j.cca.2021.04.024

HUBACEK JA, DUSEK L, MAJEK O, ADAMEK V, CERVINKOVA T, DLOUHA D, PAVEL J, ADAMKOVA V: CCR5 32 deletion as a protective factor in Czech first-wave COVID-19 subjects. Physiol Res 70: 111-115, 2021c. https://doi.org/10.33549/physiolres.934647

KARCIOGLU BATUR L, HEKIM N: The role of DBP gene polymorphisms in the prevalence of new coronavirus disease 2019 infection and mortality rate. J Med Virol 93: 1409-1413, 2021. https://doi.org/10.1002/jmv.26409

KIM YC, JEONG BH: Strong correlation between the case fatality rate of COVID-19 and the rs6598045 single nucleotide polymorphism (SNP) of the interferon-induced transmembrane protein 3 (IFITM3) gene at the population-level. Genes (Basel) 12: 42, 2020. https://doi.org/10.3390/genes12010042

KRISTIANSEN H, SCHERER CA, MCVEAN M, IADONATO SP, VENDS S, THAVACHELVAM K, STEFFENSEN TB, HORAN KA, KURI T, WEBER F, PALUDAN SR, HARTMANN R: Extracellular 2'-5' oligoadenylate synthetase stimulates RNase L-independent antiviral activity: a novel mechanism of virusinduced innate immunity. J Virol 84: 11898-11904, 2010. https://doi.org/10.1128/JVI.01003-10

KUO CL, PILLING LC, ATKINS JL, MASOLI JAH, DELGADO J, KUCHEL GA, MELZER D: APOE e4 genotype predicts severe COVID-19 in the UK Biobank community cohort. J Gerontol A Biol Sci Med Sci 75: 2231-2232, 2020. https://doi.org/10.1093/gerona/glaa131

LASSALE C, GAYE B, HAMER M, GALE CR, BATTY GD: Ethnic disparities in hospitalisation for COVID-19 in England: The role of socioeconomic factors, mental health, and inflammatory and pro-inflammatory factors in a community-based cohort study. Brain Behav Immun 88: 44-49, 2020. https://doi.org/10.1016/j.bbi.2020.05.074

LEHRER S, RHEINSTEIN PH: Homozygosity for rs17775810 minor allele associated with reduced mortality of COVID-19 in the UK Biobank Cohort. In Vivo 35: 965-968, 2021. https://doi.org/10.21873/invivo.12338

LIU YC, KUO RL, SHIH SR: COVID-19: The first documented coronavirus pandemic in history. Biomed J 43: 328-333, 2020. https://doi.org/10.1016/j.bj.2020.04.007

LIU N, ZHANG T, MA L, ZHANG H, WANG H, WEI W, PEI H, LI H: The impact of ABO blood group on COVID-19 infection risk and mortality: A systematic review and meta-analysis. Blood Rev 48: 100785, 2020. https://doi.org/10.1016/j.blre.2020.100785 
MAHLEY RW: Apolipoprotein E: from cardiovascular disease to neurodegenerative disorders. J Mol Med (Berl) 94: 739-746, 2016. https://doi.org/10.1007/s00109-016-1427-y

MEHTA P, MCAULEY DF, BROWN M, SANCHEZ E, TATTERSALL RS, MANSON JJ; HLH ACROSS SPECIALITY COLLABORATION, UK: COVID-19: consider cytokine storm syndromes and immunosuppression. Lancet 395: 1033-1034, 2020. https://doi.org/10.1016/S0140-6736(20)30628-0

MISTRY S, HARRISON JR, SMITH DJ, ESCOTT-PRICE V, ZAMMIT S: The use of polygenic risk scores to identify phenotypes associated with genetic risk of bipolar disorder and depression: A systematic review. J Affect Disord 234: 148-155, 2018. https://doi.org/10.1016/j.jad.2018.02.005

NADKARNI GN, GIGNOUX CR, SOROKIN EP, DAYA M, RAHMAN R, BARNES KC, WASSEL CL, KENNY EE: Worldwide frequencies of APOL1 renal risk variants. N Engl J Med 379: 2571-2572, 2018. https://doi.org/10.1056/NEJMc1800748

OVSYANNIKOVA IG, HARALAMBIEVA IH, CROOKE SN, POLAND GA, KENNEDY RB: The role of host genetics in the immune response to SARS-CoV-2 and COVID-19 susceptibility and severity. Immunol Rev 296: 205-219, 2020. https://doi.org/10.1111/imr.12897

PACES J, STRIZOVA Z, SMRZ D, CERNY J: COVID-19 and the immune system. Physiol Res 69: 379-388, 2020. https://doi.org/10.33549/physiolres.934492

PAIM AAO, LOPES-RIBEIRO Á, DAIAN E SILVA DSO, ANDRADE LAF, MORAES TFS, BARBOSA-STANCIOLI EF, DA FONSECA FG, COELHO-DOS-REIS JG: Will a little change do you good? A putative role of polymorphisms in COVID-19. Immunol Lett 235: 9-14, 2021. https://doi.org/10.1016/j.imlet.2021.04.005

PATI A, PADHI S, SUVANKAR S, PANDA AK: Minor allele of interferon-induced transmembrane protein 3 polymorphism (rs12252) is covered against severe acute respiratory syndrome coronavirus 2 infection and mortality: A worldwide epidemiological investigation. J Infect Dis 223: 175-178, 2021a. https://doi.org/10.1093/infdis/jiaa630

PATI A, PADHI S, PANDA D, SUVANKAR S, PANDA AK: A cluster of differentiation 14 (CD14) polymorphism (C-159T rs2569190) is associated with SARS-CoV-2 infection and mortality in the European population. J Infect Dis 2021: jiab180, 2021b. https://doi.org/10.1093/infdis/jiab180

PAIRO-CASTINEIRA E, CLOHISEY S, KLARIC L, BRETHERICK AD, RAWLIK K, PASKO D, WALKER S, PARKINSON N, FOURMAN MH, RUSSELL CD, FURNISS J, RICHMOND A, GOUNTOUNA E, WROBEL N, HARRISON D, WANG B, WU Y, MEYNERT A, GRIFFITHS F, OOSTHUYZEN W, ET AL.: Genetic mechanisms of critical illness in COVID-19. Nature 591: 92-98, 2021. https://doi.org/10.1038/s41586-020-03065-y

PENDU JL, BREIMAN A, ROCHER J, DION M, RUVOËN-CLOUET N: ABO blood types and COVID-19: Spurious, anecdotal, or truly important relationships? A reasoned review of available data. Viruses 13: 160, 2021. https://doi.org/10.3390/v13020160

PETROSILLO N, VICECONTE G, ERGONUL O, IPPOLITO G, PETERSEN E: COVID-19, SARS and MERS: are they closely related? Clin Microbiol Infect 26: 729-734, 2020. https://doi.org/10.1016/j.cmi.2020.03.026

POURALI F, AFSHARI M, ALIZADEH-NAVAEI R, JAVIDNIA J, MOOSAZADEH M, HESSAMI A: Relationship between blood group and risk of infection and death in COVID-19: a live meta-analysis. New Microbes New Infect 37: 100743, 2020. https://doi.org/10.1016/j.nmni.2020.100743

RAISI-ESTABRAGH Z, MCCRACKEN C, BETHELL MS, COOPER J, COOPER C, CAULFIELD MJ, MUNROE PB, HARVEY NC, PETERSEN SE: Greater risk of severe COVID-19 in Black, Asian and minority ethnic populations is not explained by cardiometabolic, socioeconomic or behavioural factors, or by $25(\mathrm{OH})$-vitamin D status: study of 1326 cases from the UK Biobank. J Public Health (Oxf) 42: 451-460, 2020. https://doi.org/10.1093/pubmed/fdaa095

SAADAT M: No significant correlation between ACE Ins/Del genetic polymorphism and COVID-19 infection. Clin Chem Lab Med 58: 1127-1128, 2020. https://doi.org/10.1515/cclm-2020-0577

SAMSON M, LIBERT F, DORANZ BJ, RUCKER J, LIESNARD C, FARBER CM, SARAGOSTI S, LAPOUMEROULIE C, COGNAUX J, FORCEILLE C, MUYLDERMANS G, VERHOFSTEDE C, BURTONBOY G, GEORGES M, IMAI T, RANA S, YI Y, SMYTH RJ, COLLMAN RG, DOMS RW, ET AL.: Resistance to HIV-1 infection in caucasian individuals bearing mutant alleles of the CCR-5 chemokine receptor gene. Nature 382: 722-725, 1996. https://doi.org/10.1038/382722a0 
SEVERE COVID-19 GWAS GROUP, ELLINGHAUS D, DEGENHARDT F, BUJANDA L, BUTI M, ALBILLOS A, INVERNIZZI P, FERNÁNDEZ J, PRATI D, BASELLI G, ASSELTA R, GRIMSRUD MM, MILANI C, AZIZ F, KÄSSENS J, MAY S, WENDORFF M, WIENBRANDT L, UELLENDAHL-WERTH F, ZHENG T, ET AL: Genomewide association study of severe Covid-19 with respiratory failure. N Engl J Med 383: 1522-1534, 2020. https://doi.org/10.1056/NEJMoa2020283

SHI J, LIU Y, LIU Y, LI Y, QIU S, BAI Y, GU Y, LUO J, CUI H, LI Y, ZHAO Q, ZHANG K, CHENG Y: Association between ApoE polymorphism and hypertension: A meta-analysis of 28 studies including 5898 cases and 7518 controls. Gene 675: 197-207, 2018. https://doi.org/10.1016/j.gene.2018.06.097

SHIRATO K, KAWASE M, MATSUYAMA S: Wild-type human coronaviruses prefer cell-surface TMPRSS2 to endosomal cathepsins for cell entry. Virology 517: 9-15, 2018. https://doi.org/10.1016/j.virol.2017.11.012

SRIVASTAVA A, BANDOPADHYAY A, DAS D, PANDEY RK, SINGH V, KHANAM N, SRIVASTAVA N, SINGH PP, DUBEY PK, PATHAK A, GUPTA P, RAI N, SULTANA GNN, CHAUBEY G: Genetic association of ACE2 rs2285666 polymorphism with COVID-19 spatial distribution in India. Front Genet 11: 564741, 2020. https://doi.org/10.3389/fgene.2020.564741

TALMUD PJ, COOPER JA, MORRIS RW, DUDBRIDGE F, SHAH T, ENGMANN J, DALE C, WHITE J, MCLACHLAN S, ZABANEH D, WONG A, ONG KK, GAUNT T, HOLMES MV, LAWLOR DA, RICHARDS M, HARDY R, KUH D, WAREHAM N, LANGENBERG C, ET AL.: Sixty-five common genetic variants and prediction of type 2 diabetes. Diabetes 64: 1830-1840, 2015. https://doi.org/10.2337/db14-1504

TORRE-FUENTES L, MATÍAS-GUIU J, HERNÁNDEZ-LORENZO L, MONTERO-ESCRIBANO P, PYTEL V, PORTA-ETESSAM J, GÓMEZ-PINEDO U, MATÍAS-GUIU JA: ACE2, TMPRSS2, and Furin variants and SARS-CoV-2 infection in Madrid, Spain. J Med Virol 93: 863-869, 2021. https://doi.org/10.1002/jmv.26319

VALENTI L, GRIFFINI S, LAMORTE G, GROVETTI E, UCEDA RENTERIA SC, MALVESTITI F, SCUDELLER L, BANDERA A, PEYVANDI F, PRATI D, MERONI P, CUGNO M: Chromosome 3 cluster rs 11385942 variant links complement activation with severe COVID-19. J Autoimmun 117: 102595, 2021. https://doi.org/10.1016/j.jaut.2021.102595

VAŠKŮ A: Covid-19 infection and the host genetic predisposition: does it exist? Physiol Res 69: 511-514, 2020. https://doi.org/10.33549/physiolres.934504

VERMA S, ABBAS M, VERMA S, KHAN FH, RAZA ST, SIDDIQI Z, AHMAD I, MAHDI F: Impact of I/D polymorphism of angiotensin-converting enzyme 1 (ACE1) gene on the severity of COVID-19 patients. Infect Genet Evol 91: 104801, 2021. https://doi.org/10.1016/j.meegid.2021.104801

WU BB, GU DZ, YU JN, YANG J, SHEN WQ: Association between ABO blood groups and COVID-19 infection, severity and demise: A systematic review and meta-analysis. Infect Genet Evol 84: 104485, 2020. https://doi.org/10.1016/j.meegid.2020.104485

YAMAMOTO N, ARIUMI Y, NISHIDA N, YAMAMOTO R, BAUER G, GOJOBORI T, SHIMOTOHNO K, MIZOKAMI M: SARS-CoV-2 infections and COVID-19 mortalities strongly correlate with ACE1 I/D genotype. Gene 758: 144944, 2020. https://doi.org/10.1016/j.gene.2020.144944

ZEBERG H, PÄÄBO S: The major genetic risk factor for severe COVID-19 is inherited from Neanderthals. Nature 587: 610-612, 2020. https://doi.org/10.1038/s41586-020-2818-3

ZHANG Y, QIN L, ZHAO Y, ZHANG P, XU B, LI K, LIANG L, ZHANG C, DAI Y, FENG Y, SUN J, HU Z, XIANG H, KNIGHT JC, DONG T, JIN R: Interferon-induced transmembrane protein 3 genetic variant rs12252-C associated with disease severity in coronavirus disease 2019. J Infect Dis 222: 34-37, 2020. https://doi.org/10.1093/infdis/jiaa224

ZHAO J, LIN G, ZHANG WH, GE M, ZHANG Y: Contribution of CD14-159C/T polymorphism to tuberculosis susceptibility: a meta-analysis. Int J Tuberc Lung Dis 17: 1472-1478, 2013. https://doi.org/10.5588/ijtld.13.0264

ZHOU S, BUTLER-LAPORTE G, NAKANISHI T, MORRISON DR, AFILALO J, AFILALO M, LAURENT L, PIETZNER M, KERRISON N, ZHAO K, BRUNET-RATNASINGHAM E, HENRY D, KIMCHI N, AFRASIABI Z, REZK N, BOUAB M, PETITJEAN L, GUZMAN C, XUE X, TSELIOS C, ET AL.: A Neanderthal OAS1 isoform protects individuals of European ancestry against COVID-19 susceptibility and severity. Nat Med 27: 659-667, 2021. https://doi.org/10.1038/s41591-021-01281-1 